\title{
Claire Beauchamp Randall Fraser (Outlander): postać a kody kulturowe
} serii powieści Diany Gabaldon, to angielska sanitariuszka, która w roku 1946 przenosi się do osiemnastowiecznej Szkocji w przededniu powstania Jakobitów. Zarówno serial, jak i cykl powieści, to swoisty amalgamat gatunkowy oparty na motywie podróży w czasie. Bohaterka, przenosząc się 200 lat wstecz, funkcjonuje w uwarunkowaniach kulturowych i historycznych odmiennych od tych, które zna. Pozwala to na zderzenie jej dwudziestowiecznej mentalności, wiedzy, poglądów oraz języka ze światem, w którym obowiązują odmienne kody kulturowe. Moim celem jest zastanowienie się nad tym, czy Claire reprezentuje nową postać w literaturze i kulturze wizualnej: czy jest to nowy bohater, czy bohater w nowej sytuacji; oraz w jaki sposób autorka serii buduje atrakcyjność postaci, bazując na kodach kulturowych i na czym polega fenomen Claire oraz serii, w której się pojawia.

Diana Gabaldon (ur. 1952) napisała osiem powieści w serii Outlander: Outlander (Cross Stitch w UK) (1991), Dragonfly in Amber (1992), Voyager (1994), Drums of Autumn (1997), The Fiery Cross (2001), A Breath of Snow and Ashes (2005), An Echo in the Bone (2009) oraz Written in My Own Heart's Blood (2014). Obecnie pracuje nad dziewiątą powieścią w cyklu - Go Tell the Bees That I Am Gone. Seria, określona przez krytyków jako „najinteligentniejsze połączenie historycznego przygodowego sci-fi z romansem, jakie kiedykolwiek napisał naukowiec z doktoratem", sprzedała się w 28 milionach egzemplarzy, publikowana jest w 26 krajach i przetłumaczona została na 23 języki ${ }^{1}$. Na jej podstawie Ronald D. Moore stworzył serial dla stacji telewizyjnej Starz. Dotychczas ukazały się trzy sezony, każdy na

1 Gabaldon ma stopnie naukowe z zoologii, biologii morskiej i doktorat z ilościowej ekologii behawioralnej. Zanim zaczęła pisać książki, zajmowała stanowisko profesora na Uniwersytecie Stanowym Arizona. Informacje na podstawie oficjalnej strony internetowej autorki (http://www.dianagabaldon.com/) oraz wydawcy wersji polskich (https://www.swiatksiazki.pl/). Tłumaczenie z języka angielskiego — EKL. 
podstawie kolejnej książki (choć z przesunięciami fabularnymi). Zarówno powieści, jak i serial, mają grono aktywnych na fandomach wielbicieli.

Tłem dla stworzenia bohaterki jest połączenie kilku gatunków literackich oraz budowanie akcji z zachowaniem charakterystycznej dualności. Jak twierdzi autorka, pierwsza powieść powstała z ciekawości, gdyż chciała poznać w praktyce proces pisania książek. Dlatego zdecydowała się umieścić fabułę w przeszłości, co wymagało badań historycznych i kulturowych ${ }^{2}$. Gabaldon łączy wątki romansowe z dramatem historycznym i literaturą fantasy, głównie opierając się na podróży w czasie. Sięga po motywy typowe dla literatury szkockiej, w której jednym z przewodnich elementów jest dualizm odzwierciedlający skomplikowaną sytuację historyczną, kulturową, językową Szkocji i jej zależności od Anglii, a także nawiązujący do różnic geograficznych i kulturowych między poszczególnymi częściami kraju. Dwa kanoniczne teksty literatury szkockiej - The Private Memoirs and Confessions of a Justified Sinner (1824) Jamesa Hogga i The Strange Case of Dr. Jekyll and Mr. Hyde (1886) Roberta Louisa Stevensona - bazują właśnie na motywie dualności. Jest on też twórczo przetwarzany w najnowszej literaturze szkockiej, choćby przez Emmę Tennant w Two Women of London: The Strange Case of Ms Jekyll and Mrs Hyde (1989) czy Alasdaira Gray'a w Lanark (1981) oraz takich autorów jak Alice Thompson, Ali Smith, Jackie Kay (Szymańska-Sabala 2018: 154). Gabaldon czerpie z tradycji literatury szkockiej i wprowadza motyw dualności na różnych poziomach. Zderza ze sobą epoki historyczne (druga połowa XX wieku i XVIII wiek ${ }^{3}$ ), rejony geograficzne często stawiane w opozycji (m.in. Szkocja i Anglia, Anglia i Francja, Zjednoczone Królestwo i Stany Zjednoczone, imperium Brytyjskie i kolonie), kultury (współczesną angielską i dawną szkocką), języki (angielski, szkocki i gaelicki), osobowości (łagodny Frank Randall i sadystyczny Jack Randall oraz powściągliwy Frank i niepohamowany James Fraser). $\mathrm{Na}$ tym spolaryzowanym tle umieszcza swoją bohaterkę, która staje się jednym z elementów świata zbudowanego na opozycjach, co odzwierciedla już choćby jej francusko-angielsko-szkockie nazwisko. Główna postać to Angielka w Szkocji, kobieta wśród mężczyzn, posiadająca wiedzę medyczną wśród laików. Czy Claire jest nową postacią w literaturze?

Postać kobiety obecna jest w literaturze od zawsze. Bohaterki kobiece to matki, kochanki, gospodynie domowe, ale też morderczynie i zbrodniarki. W mitologii i literaturze greckiej Helena i Afrodyta reprezentują kobietę-obiekt adoracji/pożądania, Antygona to kobieta rozdarta wewnętrznie, Hippolita to wojowniczka, Fedra opętana jest pożądaniem, Hestia to bogini domowego ogniska, a Demeter to Bogini Matka - uosobienie płodności i macierzyństwa (por. Graves 2009). W antologii Women in Literature: Reading Through the Lens of Gender, poświęconej postaciom kobiecym w literaturze i sposobom przedstawienia kobiecości i męskości, redaktorzy identyfikują około 30 zagadnień tematycznych związanych z toposem kobiety m.in.: władza mężczyzn nad kobietami; ograniczone opcje małżeństwa dla kobiet; kobiety niezamężne; postaci kobiece przełamujące stereotypy płciowe; postaci kobiece poddające się tym stereotypom; matki i córki; kobiety a pieniądze i praca; „męskość" kobiet; kobiety jako obiekty seksualne; poszukiwanie wolności przez kobiety; przemoc wobec kobiet; kobiety a samobójstwo; kobiety a szaleństwo; proto-feministki; kobieta jako femme fatale; marginalizacja kobiet; niezrozumienie kobiet przez mężczyzn; kobiety opre-

2 Za stroną autorki: http://www.dianagabaldon.com/.

3 W zależności od powieści akcja toczy się albo tuż po wojnie (1946), albo pod koniec lat sześćdziesiątych (lata 1968-1970), oraz pod koniec lat osiemdziesiątych XX wieku i jednocześnie w roku 1743, w latach 1744-46, 1766-67, 1767-70. 
syjne wobec innych kobiet (Fisher, Silber 2003: 313-318). Wiele z tych wątków przewija się w powieściach Gabaldon. Autorka buduje atrakcyjność bohaterki, odwołując się do znanych w literaturze tematów, biorąc pod uwagę zarówno czytelniczki, jak i czytelników. Z punktu widzenia odbiorcy-kobiety Claire ucieleśnia osobę świadomą równouprawnienia płci, co nie przeszkadza jej kochać i być kochaną. Jest żoną i matką, która potrafi się poświęcić dla męża i córki, ale nie zapomina o sobie i własnych pragnieniach. Stanowi dla kobiet atrakcyjny obiekt identyfikacji: potrafi panować nad swym pożądaniem, pozostaje wierna Frankowi w dwudziestowiecznym świecie, ale gdy tylko Frank umiera, nie waha się, by wrócić do Jamiego. Jest „rozważna i romantyczna”, łącząc w sobie wiele sprzeczności. Jest równie interesująca z punktu widzenia odbiorcy-mężczyzny: seksualnie wyzwolona, a jednocześnie oddana (temu mężczyźnie, z którym jest w danej epoce). Ze względu na swoje wykształcenie i doświadczenie zawodowe jest dzielną partnerką w niebezpiecznych wyprawach, a jednocześnie pozostaje kobieca. Jest troskliwa i opiekuńcza, ale sama wymaga opieki i ochrony. Gabaldon wyposażyła swoją bohaterkę w odpowiednie atrybuty, by stworzyć postać nietuzinkową: atrakcyjną, stosunkowo młodą ${ }^{4}$, ale już doświadczoną seksualnie, o silnej osobowości i własnym zdaniu, inteligentną, dzięki czemu idealnie nadawała się na bohaterkę serialu oraz zaistnienie w świecie literackim i kulturze wizualnej. Trudno jednak stwierdzić, że jest to nowy typ postaci kobiecej. Jest to raczej postać-amalgamat czerpiąca z tradycji literackiej, podobnie jak gatunkowo złożona jest sama seria.

Niemniej wydaje się, że nowatorskim elementem jest umieszczenie bohaterki w nowej sytuacji fabularnej. Powieści Gabaldon wpisują się w tradycję utworów wykorzystujących motyw podróży w czasie, ale przed Claire do przeszłości i/lub przyszłości podróżowali głównie mężczyźni, począwszy od Hanka, bohatera A Connecticut Yankee in King Arthur's Court (1889) Marka Twaina, przez anonimowego naukowca w The Time Machine (1895) H.G. Wellsa i kilka powieści Isaaca Asimova, jak choćby The End of Eternity (1955), po bardziej współczesne utwory: Time and Again (1970) Jacka Finney'a, The Man Who Folded Himself (1973) Davida Gerrolda oraz The Book of Kells (1985) R.A. MacAvoy’a — podróż Johna Thornburna i jego kochanki Derval, czy Lightning (1988) Deana Koontza — główną bohaterką jest Laura Shane, ale w czasie podróżuje tylko Stefan. Claire wydaje się zatem być pierwszą kobietą podróżującą w czasie, która zawładnęła wyobraźnią współczesnych odbiorców, stając się inspiracją dla kultury masowej, czego dowodem jest popularność serii i serialu Outlander 5 .

Jednym z zastosowanych chwytów, dzięki któremu odbiorcy zainteresowali się serią i serialem, jest „kolizja kodów”, czyli umieszczanie postaci w sytuacjach, w których następuje zderzanie czy konfrontowanie zachowań warunkowanych historycznie, kulturowo i językowo. Kolizja ta ma wymierną wartość fabularną, gdyż ujawnia różnice kodów kulturowych, ról społecznych oraz praw i obowiązków przypisywanych określonym płciom. Jednym z tematów w literaturze traktującej o kobietach jest płeć i wątki międzykulturowe (Fisher i Silber 2003: 316). Uwidaczniają się one szczególnie podczas konfrontacji przedstawicieli odmiennych płci i kultur, co stanowi fabularną podstawę serii Outlander. Clotaire Rapaille definiuje kod kulturowy jako znaczenie, które nieświadomie przypisujemy jakiejkolwiek rzeczy poprzez kulturę, w jakiej zostaliśmy wychowani (Rapaille 2006: 5). Jest to sposób

4 Clair starzeje się w kolejnych tomach, co próbują (dość niewiarygodnie) odtworzyć twórcy serialu.

5 Premiera sezonu 3, 10 września 2017 r., zgromadziła rekordową widownię (niemal 1,5 miliona widzów), która wzrosła przy trzech kolejnych powtórkach do 2,09 miliona (Rice 2017). 
postrzegania w danej kulturze danego zjawiska czy obiektu, uwarunkowany historycznie i geograficznie. Dzięki motywowi podróży w czasie oraz między różnymi obszarami etnicznymi Gabaldon tworzy postać, która konfrontuje się z odmiennymi kodami i jest tego świadoma. Stwierdzenie Claire w drugiej części serii to kwintesencja metody Gabaldon:

— Podejrzewał, że jestem czarownicą [...]. Teraz uważają mnie za wariatkę, wtedy posądzono o konszachty z diabłem. Kwestia kulturowa - wyjaśniłam. [...] - Dzisiejsza psychologia jest odpowiednikiem ówczesnej magii. Nie ma dużej różnicy.

(Uwięziona w bursztynie ${ }^{6}$ )

Jednym z elementów fabularnych (szczególnie w części pierwszej i drugiej serii) jest zestawienie dwudziestowiecznej wiedzy medycznej Claire z poziomem wiedzy medycznej w XVIII wieku. Znajomość medycyny pozwala jej przeżyć i wyrobić sobie istotną pozycję wśród Szkotów w roku 1743. Początkowo myśli, że dzięki swym umiejętnościom zaskarbi sobie wdzięczność klanu i będzie mogła łatwiej uciec, po czym okazuje się, że jako medyczka staje się dla MacKenziech zbyt cenna i pozostaje ich „zakładniczką”. Claire wykorzystuje swoją znajomość ziół, fizjologii i anatomii ludzkiej, przystosowuje się do nowych warunków i skutecznie leczy, czym zyskuje sobie szacunek Szkotów. Gdy jeszcze nie do końca zdaje sobie sprawę z tego, co się z nią stało, posługuje się współczesnym językiem medycznym, czym wprawia miejscowych w konsternację. Szybko jednak potrafi przestawić się na tok myślenia w wieku XVIII:

- Ranę trzeba najpierw zdezynfekować, a potem obandażować czystym płótnem, jeśli nie ma sterylnych bandaży.

Ogólne zdziwienie.

- Zdezynfekować? - powtórzył łysy z niejakim trudem.

- Właśnie - potwierdziłam twardo. Co za prostak, mimo poprawnej wymowy.

- Trzeba usunąć brud z rany i przemyć ją płynem zabijającym zarazki i przyspieszającym gojenie.

- Na przykład?

- Na przykład jodyną. - Nie doczekałam się odzewu. - Albo roztworem karbolowym. A może po prostu alkoholem? - Wyraz ulgi. Wreszcie znalazłam słowo, które rozumieli.

(Obca)

Dialog podkreśla rozdźwięk między postaciami pochodzącymi z różnych epok, ma wymiar komiczny, ale ukazuje intelektualną sprawność Claire, która w konfrontacji z brakiem wiedzy rozmówców szybko znajduje rozwiązanie pasujące do ich poziomu percepcji uwarunkowanego historycznie.

6 Cytaty pochodzą z ebooków, stąd brak oznaczenia numeru strony. W dalszej części przykłady zaczerpnięte są z pierwszej powieści, gdyż ilustrują one powtarzające się w serii chwyty. 
Jako medyczka Claire podróżuje z klanem, co stanowi jedną z osi akcji pierwszej powieści i wielu perypetii. Znajomość medycyny wyposaża ją w wiedzę, jakiej nie mają inni, co daje jej przewagę w nowym otoczeniu (wyraźnie eksponowany jest motyw kobiety, która ma przewagę nad mężczyznami w patriarchalnym świecie). Przykładowo, obserwując po raz pierwszy Columa, Claire zdaje sobie sprawę, że nie jest on ojcem Hamisha:

Zespół Toulouse-Lautreca. Jeszcze nigdy nie widziałam nikogo dotkniętego tą przypadłością, ale słyszałam opis. [...] Ze względu na złe krążenie krwi i degenerację tkanki łącznej osoby z zespołem Toulouse-Lautreca są nieodmiennie bezpłodne i często również stają się impotentami. Pomyślałam o Hamishu. Mój syn, powiedział Colum z dumą. Hmmm. Może zatem nie jest impotentem. A może jest. Letycja ma szczęście, że mężczyźni z rodu MacKenziech są do siebie tak bardzo podobni.

W odpowiednim momencie Claire może tę wiedzę wykorzystać. Dzieje się tak, na przykład, w części drugiej, gdy symuluje wystąpienie symptomów ospy u ludzi hrabiego St. Germain, w wyniku czego ten ostatni traci majątek.

Profesja Claire służy do wprowadzania dramatycznych zwrotów akcji. Jej instynktowne zachowania, ale też przemyślane decyzje oparte na wiedzy, prowadzą do nowych perypetii, posuwających akcję do przodu. Jednym z takich zwrotów wynikających z kolizji kodów: zderzenia wiedzy i instynktu współczesnej pielęgniarki z XVIII-wieczną kulturą i mentalnością, jest oskarżenie Claire o to, że jest czarownicą. Procesy czarownic były rozpowszechnione w Szkocji od przełomu XVI i XVII wieku i wiele osób wierzyło w czary. Król Jakub VI Szkocji i I Anglii (1566-1625) w roku 1597 napisał traktat o czarownicach Daemonologie i sam uczestniczył w ich procesach (Rutkowski 2018: 21-22). Polowania na czarownice były szczególnie częste w XVII wieku, a ich echem, mniej więcej 100 lat później, jest proces Claire i Geilis Duncan, innej podróżniczki w czasie. Oskarżenia opierają się na tym, że bohaterki wykorzystują magię, choć w rzeczywistości umiejętnie korzystają ze stanu wiedzy medycznej w XX wieku. Claire oskarżona zostaje też o zabicie noworodka i zostawienie w jego miejsce odmieńca, co jest skutkiem jej dążenia do uratowania dziecka pozostawionego przez miejscowych dla Małego Ludka. Claire nie rozumie lokalnych wierzeń ludowych i chce ratować chore niemowlę za wszelką cenę, łamiąc przy tym obowiązujący kod kulturowy. Choć udaje jej się ocalić życie, to niewiele brakowało, by faktycznie je straciła. Tak jak w przypadku Geilis przyczyną byłaby blizna po szczepieniu na ospę, którą uznano za znak diabła:

Gdy Geilis odwróciła się z wysoko wyciągniętymi ramionami, ujrzałam to, co ona zobaczyła na moim ciele, gdy zdarto ze mnie ubranie. Znamię na ramieniu, takie samo jak moje. Tutaj, w tych czasach, piętno szatana, znak magów. Mała, znajoma blizna po szczepionce przeciwko ospie. 
Gabaldon wykorzystuje informacje historyczne, żeby uprawdopodobnić wydarzenia w świecie przedstawionym wynikające z kolizji dwóch historycznych światów. Znak diabła (Devil's Mark - Signum Diabolicum), czyli rana zostawiana na ludzkim ciele przez demona jako dowód na zawarcie z nim paktu, wykorzystywany był do identyfikowania czarownic (Rutkowski 2018: 26). Gabaldon odwołuje się do tego konceptu, pokazując w jak odmienny sposób interpretowany jest ten sam obiekt w zależności od okresu historycznego i stanu wiedzy.

Kolizja kodów kulturowych prowadzi też do napięć między bohaterami i podkreślania obcości Claire w świecie, do którego się przeniosła, a pośrednio do obcości tego świata dla współczesnego czytelnika. Ponieważ Claire brak jest wiedzy na temat zachowań w dawnej Szkocji, łamie obowiązujące (i przypisane do płci) zasady postępowania, z czego zwykle nie zdaje sobie sprawy. Przykładowo, kierując się dobrem Jamiego, bez podtekstów seksualnych, Claire proponuje mu spanie w jej pokoju:

— Nie możesz tu spać — zaprotestowałam. — Wejdź, podłoga w pokoju nie jest aż tak brudna. [...]

— Spać w jednym pokoju z tobą? Nigdy! Byłabyś zhańbiona!

$(\mathrm{Obca})$

Propozycja, która dla niej jest naturalna i neutralna, odbierana jest jako złamanie zasad moralnych. Często tylko troska Jamiego ratuje bohaterkę z opresji wynikających z nieznajomości odpowiednich zachowań. Odruchowe postępowanie bohaterki pokazuje, jak dalece nastąpiła emancypacja kobiet ${ }^{7}$.

Gabaldon, wybierając na bohaterów współczesną, pracującą kobietę i przywódcę klanu sprzed 200 lat, zderza dwa światy: patriarchalny, w którym wychował się Jamie, i ten, w którym kobiety zaczęły upominać się o swoje prawa. Claire ma własne zdanie i decyduje o sobie. Nie należy do kobiet, które podporządkowują się mężczyznom, co nadaje jej rys feministyczny w tym sensie, że wierzy w równouprawnienie płci i wartością jest dla niej samostanowienie. Jamie odbiera to nie tylko jako złamanie zasad, ale przede wszystkim zagrożenie, gdy niezależność Claire naraża życie innych: „Przywykłaś, że sama o sobie decydujesz i wiem [...] że nie pozwalasz mężczyźnie sobą rządzić. Ale musisz się tego nauczyć, dla dobra nas wszystkich” (Obca). $\mathrm{Na}$ tym polu często dochodzi do starć między nią, a jej szkockim mężem, w którego patriarchalnym świecie posłuszeństwo żony jest wartością niepodważalną. Ilustruje to jedna z kłótni:

- Nie chcę się z tobą kochać! [...]

- Nie pytałem, czego chcesz. Angielko. - Głos Jamiego brzmiał złowieszczo spokojnie. - Jesteś moją żoną, co powtarzałem ci dość często. Mogłaś za mnie nie wychodzić, a jednak zdecydowałaś inaczej. A jeśli przypadkiem nie zauważyłaś, w twojej przysiędze znajdowało się słowo „posłuszeństwo”. Jesteś moją żoną i jeśli cię zechcę, kobieto, mogę cię wziąć, do stu diabłów! [...]

Motyw emancypacji kobiet (ale też równych praw dla mniejszości etnicznych) Gabaldon przedstawia także z punktu widzenia XX wieku. W kolejnej części, gdy Claire wraca do współczesnych czasów i przenosi się do Stanów Zjednoczonych, jest jedyną kobietą w gronie studentów medycyny (przy okazji innym „obcym” w tym gronie jest Afroamerykanin). 
— Tak, do stu diabłów, jeśli na to pozwolę, ty brutalu! Wydaje ci się, że możesz mnie zmusić? Wykorzystać jak ladacznicę, ponieważ tak ci się podoba? Nie możesz, ty pieprzony bydlaku!

$(\mathrm{Obca})$

Z czasem Jamie w coraz większym stopniu akceptuje odmienność Claire, ale i ona musi nauczyć się chodzić na ustępstwa. Nie mamy tu do czynienia z „wojną płci”, lecz z pozytywnym wymiarem kompromisu. Przełamanie dzielących bohaterów barier kulturowych wymaga wzajemnego zrozumienia, ale też akceptacji kodów wynikających z wychowania w odmiennych realiach. Pomimo takich starań napięcia między postaciami są jednym z podstawowych elementów świata przedstawionego i jego dramatyzmu.

Ukształtowane kulturowo schematy myślowe Claire nieustannie konfrontowane z rzeczywistością historyczną (i jej regułami) stanowią także element budujący humor słowny i sytuacyjny oraz nadający bohaterce wyrazistości. Claire często przywołuje znane z jej świata i kultury koncepty, które są obce jej rozmówcom, co prowadzi do zabawnych sytuacji lub nieporozumień:

- Kto to cię nauczył tak walczyć? Także Dougal?

— Nie. - Skrzywił się, kiedy zaczęłam przemywać mu ranę octem. — Mój ojciec.

- Naprawdę? A co, był miejscowym mistrzem boksu?

- Co to jest boks? Nie, prowadził gospodarstwo. I hodował konie.

(Obca)

W tej wymianie Jamie przechodzi do porządku dziennego nad nieznanym wyrazem (i kryjącym się za nim konceptem), ale w innych przypadkach Claire wprawia swych rozmówców w konsternację: „- Dougal mógłby jeszcze stepować - mruknęłam. - Co? - Obaj wytrzeszczyli na mnie oczy" (Obca). Czasem rozmówca otwarcie stwierdza, że nie wie, o czym ona mówi. Zwykle nie prowadzi to do nieporozumień, gdyż jej wypowiedź zostaje zignorowana, tworzy jednak sytuację komiczną dla odbiorcy, który posiada tę samą wiedzę kulturową, co bohaterka i stanowi specyficzną grę kodami z czytelnikiem:

— Ty barbarzyńco! Ty... sadysto! — syknęłam z furią. - Robisz to dla własnej przyjemności! Nigdy ci tego nie wybaczę!

Jamie zatrzymał się i skrócił pas w dłoniach.

— Nie wiem, co znaczy „sadysta” — powiedział spokojnie. — A jeśli ja ci wybaczyłem to, co się dziś stało, ty też mi wybaczysz, jak tylko będziesz mogła usiąść.

$(\mathrm{Obca})$

Claire sięga także do współczesnych konceptów, gdy chce być ironiczna, co jest charakterystyczną dla niej strategią dyskursywną, jak w wymianie zdań z Murtaghiem: 
— Nie damy rady go znaleźć, lepiej pozwólmy, żeby on nas odszukał.

— W jaki sposób? Wystrzelimy rakietę? - zasugerowałam tonem pełnym

sarkazmu.

$(\mathrm{Obca})$

Podobnie wybrzmiewa jej uwaga pod adresem Jamiego: „Kim ci się, do jasnej cholery, zdaje, że jesteś? Znalazł się przemarznięty John Wayne!" (Obca). Jamie zwykle stara się zrozumieć Claire i prosi ją o wyjaśnienie. Nie zawsze wyjaśnienia cokolwiek ułatwiają: „— Kto to, na miłość boską, jest John Wayne? - To ty" (Obca). Bohaterka zdaje sobie bowiem sprawę z tego, że zrozumienie kodów kulturowych jej świata nie zawsze jest możliwe, dlatego nie wdaje się w dyskusje odkodowujące znaczenia.

W powieściach postać Claire budowana jest na odniesieniach do współczesności, które nie są czytelne na poziomie wewnątrztekstowym - sygnały takie nie są odbierane przez innych bohaterów, gdyż pojawiają się w partiach pierwszoosobowej narracji. Claire bawi się kodami, co tworzy jej poczucie humoru, jak ilustruje to kilka z wielu przykładów: przed ślubem z Jamiem (ślub jest sposobem na uratowanie jej przed Jackiem Randallem), stwierdza „- Idący na śmierć pozdrawiają cię — powiedziałam do mego odbicia w zwierciadle i zasalutowałam" $(\mathrm{Obca})$. Sędziów na procesie o czary porównuje do postaci z komiksów:

Jeden sędzia był nieprawdopodobnie wysoki i szczupły, drugi niski i korpulentny. W nieunikniony sposób przypominali postacie z amerykańskiego komiksu, który niegdyś czytywałam. Tyczkowatego nazwałam w duchu Muttem, a przysadzistego Jeffem.

$(\mathrm{Obca})$

Zadaniem odbiorcy pozatekstowego jest zidentyfikowanie znaczeń tych intertekstów.

Claire często odwołuje się do wydarzeń z II wojny światowej, co podkreśla kolizję światów: historycznego i teraźniejszego. Uwiarygodnia ją to jako współczesną postać, ukształtowaną przez wydarzenia wojenne. Czasem nawiązania te mają wydźwięk humorystyczny, jak w opisie Jamiego, który przybywa jej na ratunek w trakcie procesu czarownic: „Jamie torował sobie drogę przez tłuszczę, z twarzą ściągniętą strasznym gniewem. Bezlitośnie rozpychał tych, którzy stali mu na drodze. Poczułam się jak generał MacAuliffe pod Bastogne na widok nadciągającej Trzeciej Armii Pattona” (Obca). Czasem mają one charakter niemal filozoficzny, prowokując czytelników do pogłębionych przemyśleń:

Mężczyzna zabity kulą z muszkietu jest tak samo martwy, jak ktoś zabity pociskiem z moździerza. Tyle tylko, że moździerz zabija automatycznie i bezosobowo, niszcząc dziesiątki ludzkich istnień, a ten, kto strzela z muszkietu, widzi oczy swojej ofiary. Dlatego wszystkie dawne walki miały więcej wspólnego z morderstwem niż wojną. Ilu trzeba przeciwników, żeby uznać potyczkę za wojnę? [...] Więc co to za powody? Czy chodzi o króla, który jest lepszy od innego? 
O Hanoverów i Stuartów? Dla mnie to tylko nazwiska ze szkolnych podręczników. Kimże byli w porównaniu z niewyobrażalnym złem hitlerowskiej Rzeszy?

$(\mathrm{Obca})$

Claire, która przeżyła horror wojny, niełatwo daje się wyprowadzić z równowagi na widok rannego czy nieboszczyka. Jednak i ona w trakcie powstania Jakobitów ma problem — wykazuje wszelkie symptomy PTSD. W ten sposób tragizm i ogrom współczesnej wojny nakłada się na wojnę toczoną w Szkocji — dla Szkotów rozmiar klęski w powstaniu, a zwłaszcza masakra pod Culloden, miały równie tragiczne skutki, co II wojna światowa dla Europy.

Claire to postać konsekwentnie budowana w kontraście z pozostałymi bohaterami na wielu poziomach. Jednym z nich jest jej język. Jeszcze zanim przenosi się w czasie, ujawnia się jako osoba łamiąca konwenanse. Przekleństwa nadają jej współczesny (wyzwolony) rys, a jej język nie przystawałby XVIII-wiecznej angielskiej damie: „Chodź no tutaj, ty... przeklęty sukinsynu!”, na co Rupert stwierdza „Nigdy nie słyszałem, żeby kobieta tak gadała” (Obca). Język Claire nadaje jej zarówno wyrazistości, jak i uwypukla motyw dualności. Claire mówi doskonałą angielszczyzną, co stawia ją w opozycji do Szkotów. Podkreśla jej odrębność, gdy lokalni mieszkańcy porozumiewają się po gaelicku. Jest to język, którego Claire nie rozumie i zdana jest całkowicie na pomoc kogoś, kto wyjaśni jej, co się dzieje. Jest to szczególnie wyraźne w serialu, kiedy bohaterowie faktycznie rozmawiają ze sobą, używając języka gaelickiego, podczas gdy w powieściach Claire jedynie odnotowuje ten fakt, ewentualnie pojawiają się pojedyncze wyrazy. Język wyróżnia Claire i nadaje jej cechy silnej kobiety, jednocześnie nieustannie wskazując na jej obcość w świecie, w którym się nagle znalazła. Kolizji kodów kulturowych towarzyszy tym samym kolizja kodów językowych.

Wydaje się, że Claire jest postacią domkniętą — posiada specyficzny zestaw cech, które ją identyfikują, a świat przedstawiony jest dwuwątkowy. Wątek poboczny — romans Claire i Jamiego - pogłębia postać Claire i wskazuje na jej ewolucję. Odkrywa ona własne emocje, których nie odczuwała, będąc w związku z Frankiem, ale przede wszystkim odkrywa zupełną nieprzystawalność jej współczesnego świata i kultury, do tego sprzed 200 lat. Uczy się, że aby móc w tym nowym (dawnym) świecie funkcjonować, powinna przynajmniej do pewnego stopnia przyjąć jego reguły. Musi być elastyczna. Nie może narzucać własnych przekonań ludziom funkcjonującym według innych zasad. Gabaldon zderzając kody kulturowe, nie wartościuje ich - pokazuje ich odmienność.

$\mathrm{Na}$ czym zatem polega fenomen Claire jako postaci i serii Obca? Gabaldon sięgając po różne konwencje gatunkowe, łącząc w jednej postaci uwarunkowania społeczno-kulturowe z różnych epok, stworzyła serię powieści i bohaterkę, które odczytywać można w różnych wymiarach. W wymiarze filozoficznym stawia pytanie o to, czy można zmienić przyszłość. Bohaterka pochodząca z przyszłości, znając historię, stara się zapobiec tragicznym wydarzeniom i uratować dziesiątki Szkotów skazanych na śmierć w bitwie pod Culloden, co miałoby niewątpliwie wpływ na przyszłość. Wątek ten związany jest z wymiarem egzystencjalno-etycznym, w którym pytaniem zasadniczym jest to, czy można zabić kogoś w przeszłości, wpływając na bieg zdarzeń w przyszłości. Nawet przyjęte reguły fantasy nie pozwalają jednak na to, by doprowadzić do zmiany przeszłości, wykorzystując wiedzę z przyszłości. Ostatecznie wszystkie wysiłki Claire i Jamiego, by nie doszło do bitwy pod Culloden, spełzają na niczym, a rzeź, tak jak to miało miejsce w rzeczywistości pozatekstowej, dokonuje się. W wymiarze 
etycznym Claire musi skonfrontować się z pytaniem, czy można zabić niewinnego człowieka, by ratować siebie i bliskich. To pytanie nie jest już tak abstrakcyjne jak poprzednie i dotyczyć może czytelnika w prawdziwym życiu. Podobnie jak kwestia uczuciowa: czy można kochać dwóch mężczyzn jednocześnie. Claire uwikłana jest w dwa małżeństwa: pozostaje żoną Franka Randalla w dwudziestym wieku i żoną Jamiego Frasera w osiemnastym. Obu mężczyzn kocha, choć każda z tych miłości jest inna, o innej intensywności (również w sferze erotycznej). W wymiarze romantycznym seria uwypukla romantyczną miłość, gdyż zdecydowanie przeważa związek z Jamiem. W wymiarze estetycznym podkreślone jest piękno i atrakcyjność cielesna postaci, ale też dzikiej scenerii Szkocji, tworzącej tło dla wątków rozgrywających się w przeszłości. W końcu seria ma bez wątpienia wymiar historyczny — dobrze zarysowane jest tło dziejowe, dzięki czemu, pomimo elementów fantasy, seria ma walor edukacyjny i poznawczy. W atrakcyjny sposób przedstawia wydarzenia historyczne, pokazując jak do nich doszło.

Wielowymiarowość głównej bohaterki i tematyki serii, a przede wszystkim główny motyw pierwszej powieści w cyklu, sprawiły, że Gabaldon ma wielu naśladowców (naśladowczyń). Prześledzenie rynku wydawniczego uprawnia do stwierdzenia, że zapoczątkowała ona modę na cykle powieści z motywem podróży w czasie, których akcja rozgrywa się w Szkocji. Tym samym stworzyła swoisty wzorzec, do którego odwołują się inni. Dość wymienić takie serie jak: Highlander Karen Marie Moning - Beyond the Highland Mist (1999), To Tame a Highland Warrior (1999), The Highlander's Touch (2000), Kiss of the Highlander (2001), The Dark Highlander (2002), The Immortal Highlander (2004), Spell of the Highlander (2005), Into The Dreaming (2006); cykl powieści Veronici Wolff - Master of the Highlands (2008), Sword of the Highlands (2008), Warrior of the Highlands (2009), Lord of the Highlands (2009); cykl MacCoinnich Catherine Bybee - Binding Vows (2013), Silent Vows (2013), Redeeming Vows (2013), Highland Shifter (2012), Highland Protector (2013); Córki dolin Melissy Mayhue - Thirty Nights with a Highland Husband (2007), Highland Guardian (2007), Soul of a Highlander (2008), A Highlander of Her Own (2009), A Highlander's Destiny (2009), A Highlander's Homecoming (2010), Healing the Highlander (2011), Highlander's Curse (2011); Zamek Blackstone Sandy Blair - A Man in a Kilt (2004), A Rogue in a Kilt (2004), A Thief in a Kilt (2006), The Warrior (2013); Loch Moigh Barbary Longley - True to the Highlander (2014), The Highlander's Bargain (2014), The Highlander's Folly (2015), The Highlander's Vow (2016); Highland Sorcery Clover Autrey - Highland Sorcerer (2012), The Vampire and the Highland Empath (2012), Highland Shapeshifter (2012), Highland Moon Sifter (2013), A Highland Sorcery Christmas (2013), Highland Son (2014), Highland Illusion (2015), Highland Soldier (2016); cykl Lekcje Jennifer Connors - A Lesson in Passion (2009), A Lesson in Forgiveness (2010), A Lesson in Patience (2010), A Lesson in Friendship (2011), A Lesson in Presumption (2011), A Lesson in Trust (2012), A Lesson in Sacrifice (2012), A Lesson in Pride (2013), A Lesson in Love (2014); cykl powieści Debbie Mazzuci - Lord of the Isles (2010), Warrior of the Isles (2011), King of the Isles (2012). Do tego katalogu dołączyć należy powieści takich autorek jak: Jo Barrett (Highlander's Challenge, 2007), Kat Bastion (Forged in Dreams and Magick, 2011; Bound by Wish and Mistletoe, 2013), Ceci Giltenan (The Pocket Watch, 2015; The Midwife, 2016), Maxine Mansfield (Time for a Highlander, 2016), Jessi Gage (Wishing For a Highlander, 2014; The Wolf and the Highlander, 2014; Choosing the Highlander, 2015), Susan Sizemore (A Kind of Magic, 2006), Laura Hunsaker (Highland Destiny, 2010) ${ }^{8}$.

$8 \mathrm{Na}$ podstawie „kwerendy internetowej”, w tym między innymi informacji (Listopii) z portalu goodreads: https://www.goodreads.com/list/show/86298.Best_Scottish_Highland_Time_Travel_Romance. 
Co ciekawe, wszystkie te powieści i cykle napisane zostały przez kobiety i wszystkie przez Amerykanki.

Dość pobieżna analiza pozwoliła na zidentyfikowanie ponad 60 powieści wydanych po Obcej, które choć różnią się w szczegółach, oparte są na analogicznym schemacie. Wszystkie te powieści łączy postać współczesnej kobiety, często o silnej osobowości, często wykształconej (lekarka, archeolog itd.), która nieoczekiwanie znajduje się w Szkocji z przeszłości. Potyczki klanów, bitwy, opisy szkockich krajobrazów to nieodłączny element tych utworów, podobnie jak romans z przystojnym szkockim góralem (często jest to przywódca klanu — „inteligentny barbarzyńca”). Postać męską tych utworów podsumować można słowami Claire, gdy ujrzała Jamiego przed ślubem: „Szkocki góral w pełnym rynsztunku zawsze wygląda imponująco, nawet jeśli jest stary, brzydki lub niezgrabny. Młody, wysoki i całkiem niebrzydki Szkot to zjawisko zapierające dech w piersiach” $(\mathrm{Obca})$. Bez wątpienia wszystkie te amerykańskie pisarki wzorowały się na pierwszej powieści Gabaldon i jej bohaterce, ukazując, o czym marzą amerykańskie kobiety: skoro powstało tak wiele podobnych utworów, to znaczy, że jest na nie zapotrzebowanie i wyrażają one tęsknoty odbiorców (czytelniczkami są głównie kobiety, jak wynika z zamieszczanych internetowych recenzji). Jak zauważa Piotr Gociek: „Nawet gdy zainteresowanie literaturą w ogóle spada, w kryzysowych chwilach mocno trzyma się $\mathrm{z}$ reguły literatura eskapistyczna: od romansu do fantastyki. Potrzeba ucieczki w krainę fikcji jest — jak się okazuje — niemal równie silna jak potrzeba jedzenia i picia” (2012). Wymienione powieści wydają się stanowić jeden z nurtów amerykańskiej współczesnej literatury eskapistycznej - pisanej przez kobiety głównie dla kobiet, które pragną (choćby poprzez zagłębienie się w lekturze) uciec od współczesności (stąd motyw podróży w czasie) i codziennej rzeczywistości zdominowanej przez obowiązki i przypisane im role. Powieści te pokazują alternatywne życie, pełne przygód i romantycznej miłości. Nie jest to jednak miłość platoniczna. Silne bohaterki, które posiadają władzę dzięki swej wiedzy, dają czytelniczkom, które się z nimi identyfikują, poczucie wyjątkowości.

Claire jako postać funkcjonująca w świecie przedstawionym, w którym nieustannie kontrastowane są różne kody kulturowe, stała się bohaterką odpowiednią do zaadaptowania dla kultury wizualnej. Seksapil, inteligencja, spryt, ale także uczucie, jakim obdarza Jamiego, i bezpruderyjność stanowią o jej potencjale jako wzorca do naśladowania przez inne pisarki oraz bohaterki, który przyciągnąć może też widza. Wydaje się, że Gabaldon tworząc Claire, zapoczątkowała nowy fenomen kulturowy.

Ewa KujawsKa-LIS

https://orcid.org/0000-0003-1283-9615

Uniwersytet Warmińsko-Mazurski w Olsztynie

Katedra Filologii Angielskiej

Kontakt: ewa.kujawska-lis@uwm.edu.pl

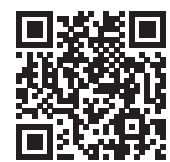




\section{Bibliografia}

Gabaldon Diana (1999), Obca, przeł. Z. Zaubert, Świat Książki, Warszawa, ebook.

- (2015), Uwięziona w bursztynie, przeł. K. Bober, E. Błaszczyk, A. Puciłowska, I. Rutkowska, L. Rafa, Świat Książki, Warszawa, ebook.

Gociek Piotr (2012), Nieznośna lekkość pisania, „Uważam Rze” 25.11, http://www.rp.pl/artykul/954503-Nieznosna-lekkosc-pisania.html [dostęp: 24.07.2018].

Graves Robert (2009), Mity greckie, przeł. H. Krzeczkowski, vis-à-vis, Kraków.

Rapaille Clotaire (2006), The Culture Code. An Ingenious Way to Understand Why People Around the World Live and Buy as They Do, Broadway Books, New York.

Rice Lynette (2017), Outlander Premiere Scores Record Ratings, „Entertainment” September 15, https://ew.com/tv/2017/09/15/outlander-premiere-ratings-season-3/ [dostęp: 24.07.2018].

Rutkowski Pawel (2018), The Devil's Mark, Black Toads and Magic Storms: King James and Witchcraft [w:] Polish Scholars on Scottish Writers. An Interpretive Collage, red. Korzeniowska A., Szymańska I., Wydawnictwo Semper, Warszawa.

Szymańska-Sabala Ewa (2018), Rewriting Glasgow Cityscape: Affirmative Duality in "So I Am Glad" by A.L. Kennedy [w:] Polish Scholars on Scottish Writers. An Interpretive Collage, red. Korzeniowska A., Szymańska I., Wydawnictwo Semper, Warszawa.

Women in Literature: Reading through the Lens of Gender (2003), red. J. Fisher, Ellen S. Silber, Greenwood Press, Westport, Connecticut, London.

http://www.dianagabaldon.com/

https://www.goodreads.com/list/show/86298.Best_Scottish_Highland_Time_Travel_Romance

https://www.swiatksiazki.pl/

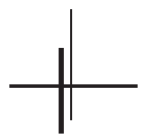

